\title{
PENINGKATAN OMSET PENJUALAN MENGGUNAKAN E-COMMERCE PADA DO'I COFFEE
}

\author{
Humisar Hasugian $^{1 *}$, Femi Kurniawati ${ }^{2}$, Faisal Fahmi Fratama ${ }^{3}$, Nada Permatasari ${ }^{4}$ \\ ${ }^{1,2,3,4}$ Fakultas Teknologi Informasi, Sistem Informasi, Universitas Budi Luhur, Jakarta Selatan, Indonesia \\ E-mail : 1*humisar.hasugian@budiluhur.ac.id, ${ }^{2} 1512500495 @$ student.budiluhur.ac.id, ${ }^{3} 1712500311 @$ student.budiluhur.ac.id, \\ 41712501855@student.budiluhur.ac.id \\ (*: coressponding author)
}

\begin{abstract}
Abstrak-Teknologi yang semakin berkembang berjalan dengan sangat cepat, banyak perubahan terjadi salah satunya pada kebiasaan berbelanja, yang pada awalnya masih melakukan transaksi jual beli secara konvensional kini sudah bergeser secara daring atau biasa disebut dengan istilah e-commerce. Adanya transaksi secara daring ini membuka peluang pemasaran menjadi lebih luas. Transaksi penjualan yang ditawarkan Do'i Coffee saat ini masih menunggu pelanggan datang ke toko sehingga tingkat penjualan makin menurun hal ini diakibatkan kalah bersaing dengan toko sejenis yang sudah menggunakan teknologi informasi. Berdasarkan masalah tersebut Do'i Coffee berniat meningkatkan penjualan dan pemasaran dengan membuat toko online menggunakan e-commerce dengan bantuan Content Management System (CMS), diharapkan dengan adanya toko online ini maka calon pelanggan dapat dengan mudah melihat informasi produk dan memesannya melalui gadget masing-masing tanpa datang langsung ke toko sehingga transaksi penjualan dan pemasaran makin meningkat karena dapat menjangkau calon pelanggan tanpa terikat waktu dan tempat.
\end{abstract}

Kata kunci: E-commerce, Content Management System, Kopi, Penjualan Kopi, Toko Online

Abstract-The Technological Developments are running very fast and causing many changes including in shopping habits that previously by conventional way of buying and selling transactions and currently shifted to by online transaction or better known as e-commerce. By using the online transaction, it will open wider network and marketing opportunities. The sales transactions offered by Do'i Coffee are currently still conventional, waiting for the customers to come to the coffee shop, so it causes the sales revenue decreased and they are unable to compete with other coffee shops that are already using the information technology.Due to these problems, Do' $i$ Coffee intends to increase the sales revenue and marketing by developing an online shop using e-commerce based on Content Management System (CMS). It is expected that by this online shop, the costumers can easily check the product information and order it through online by their gadgets without having to come directly to the coffee shop, so that the sales revenue and marketing transactions can be increased because of the online shop which can reach potential customers regardless of time and place.

Keywords: E-commerce, Content Management Systems, Coffee, Coffee Seller, Online Shop

\section{PENDAHULUAN}

Teknologi informasi berkembang dengan pesatnya diberbagai bidang ilmu, seperti dalam bidang komunikasi, pendidikan, desain ekonomi, bisnis dan lainnya mendorong setiap individu maupun organisasi memerlukan bantuan teknologi untuk membantu mempermudah pekerjaan dalam kegiatannya sehari-hari. Dengan menggunakan sistem bersifat daring seseorang dapat mengelola data, memperoleh informasi serta menyebarkan informasi yang diperlukan setiap saat dan tanpa terpengaruh oleh jarak..

Do'i coffee adalah sebuah kedai kopi yang menjual beberapa macam makanan dan minuman yang bisa dinikmati semua kalangan untuk bersantai bersama-sama. Usaha ini didirikan tahun 2017 oleh bapak Ferdiyan Adhittia. Motivasi dalam mengembangkan bisnis kedai kopi ini berawal dari keinginan sang owner untuk mulai berwirausaha dan meninggalkan pekerjaan lamanya. Pada tahun 2017 tren penikmat kopi semakin meningkat dan hal tersebut menjadi pemacu untuk segera membuka kedai dan resign dari pekerjaan lamanya. Seiring berjalannya waktu, usaha ini menunjukkan perkembangan yang semakin menurun. Diakibatkan kalah bersaing dengan usaha sejenis yang semakin banyak.

Pemesanan saat ini hanya melalui pemesanan langsung di tempat. Sistem yang saat ini dijalankan tidak dapat bekerja dengan sempurna. Seiring dengan perkembangan toko yang meningkat yang berkelanjutan transaksi yang diperoleh semakin meningkat dan data yang dikelola semakin banyak pula. Perubahan dalam pengelolaan record data juga harus dilakukan secara akurat untuk mengimbangi semakin besarnya pemesanan. Pengaplikasian sistem bisnis yang sedang berlangsung juga tidak dapat menjangkau pangsa pasar yang jauh dari lokasi toko berada, membuat perkembangan Do'i Coffee juga tidak dapat meningkat dengan signifikan, cenderung meningkat yang bergerak lambat. Latar belakang yang diuraikan di atas mendorong penulis untuk memanfaatkan teknologi informasi aberupa aplikasi penjualan (E-commerce) berbasiskan web yang dapat membuat penjualan dan pemasaran kopi menjadi lebih efektif dan efisien. E-commerce suatu proses kegiatan dalam sebuah organisasi yang terdiri atas interaksi antara pelanggan, penyedia layanan, dan pihak promosi dengan melibatkan teknologi 
komunikasi berupa jaringan komputer seperti Internet [1]. Oleh karena itu, dibuatlah sebuah "Peningkatan Omset Penjualan Menggunakan E-Commerce Pada Do'i Coffee". Penerapan e-commerce ini diharapkan dapat untuk mengelola transaksi penjualan, memudahkan pelanggan dalam memesan barang, memperluas jangkauan pasar, serta mempermudah pimpinan untuk memonitor proses bisnis yang sedang berjalan.

Masalah yang dihadapi oleh Do'i Coffee antara lain (a) Kurang efisiennya waktu dalam proses pemesanan, dikarenakan proses pemesanan hanya melalui pemesanan langsung di tempat (offline). (b) Cakupan wilayah penjualan yang kurang luas karena penjualan dan pemasaran hanya terpaku pada offline store. (c) Kesulitan dalam proses pengolahan data penjualan karena penyimpanan data penjualan yang tidak terorganisir dengan baik. (d) Sering terjadinya duplikasi data, karena data yang dikelola masih dalam bentuk tulisan dan manual report melalui pesan whatsapp yang tidak terorganisir dengan baik. (e) Sering kali data yang dihimpun hilang karena tidak terekam dengan tepat. (f) Minimnya informasi yang dapat diperoleh pelanggan, baik mengenai informasi barang yang dijual maupun informasi lanjutan mengenai seputar Do'i Coffee. Tujuan dari penelitian ini terdiri atas : (a) Merancang E-commerce berbasis web pada Do'i Coffee. (b) Mempermudah pelanggan Do'i Coffee dalam memesan produk yang dijual setiap saat tanpa terikat waktu dan jarak. (c) Menampilkan informasi barang secara up to date, sehingga memudahkan pelanggan Do'i Coffee dalam memesan barang yang mereka inginkan. (d) Memudahkan dalam menangani transaksi yang diterima, dan memudahkan dalam pemantauan bisnis yang sedang berjalan. Berdasarkan masalah yang ada, maka pembatasan masalah dilakukan bertujuan agar pemecahan masalah dapat terarah dengan baik serta menghindari meluasnya materi yang ingin diteliti. Adapun batasan masalahnya antara lain (a) Sistem informasi penjualan daring yang dibuat berupa Aplikasi website. (b) Sistem informasi penjualan daring ini hanya melibatkan Do'i Coffee sebagai project charter. (c) E-commerce yang diusulkan ini dikembangkan menggunakan WordPress dengan menggunakan plug-in Woocommerce. Sistem informasi merupakan gabungan dari semua komponen yang saling berhubungan dan memiliki keterikatan satu dengan lainnya termasuk didalamnya perangkat komputer, aplikasi komputer, dan koleksi dari banyak data [2]. Penelitian ini dilakukan dengan pengumpulan data melalui wawancara dan abservasi di toko dan melakukan analisa masalah dengan alat bantu fishbone diagram, merancang Business Model Canvas (BMC) sesuai dengan kebutuhan bisnis terkini, merancang funsionalitas sistem dengan menggunakan use case diagram sesuai dengan BMC yang dirancang, adapun pembuatan website menggunakan CMS dan database mysql, dan tahap implementasi dengan membeli hosting dan domain agar toko ini bisa diakses secara online darimana saja dan kapan saja.

\section{METODE PENELITIAN}

Metode penelitian untuk pengembangan sistem meliputi analisa, perancangan sampai dengan implementasi menggunakan waterfall model. model ini merupakan model yang sudah sering digunakan dalam pengembangan suatu sistem. Waterfall model sering disebut dengan model sekuensial berurutan atau dengan istilah lain alur hidup klasik [3]. Adapun tahapan dari metode waterfall yaitu:

a. Analisis kebutuhan, tahapan ini memerlukan komunikasi antara pengembang dengan pengguna sistem bertujuan untuk mengmpulkan kebutuhan sistem informasi pengumpulan data ini dilakukan melalui observasi, wawancara, analisa dokumen, dan juga studi literatur.

b. Desain Sistem, tahap analisa kebutuhan dipelajari dan desain sistem yang akan diusulkan dirancang dan didesain, seperti menentukan perangkat keras, perangkat lunak dan arsitektur jaringannya.

c. Implementasi Sistem, pada tahap implementasi dimulai dengan membuat program kecil, yang terintegrasi dalam tahap selanjutnya. Setelah program kecil ini diuji dan layak maka dikembangkan lebih lanjut sesuai dengan fungsionalitas dari sistem tersebut.

d. Testing Sistem, tahap ini memantau sistem yang sudah diterapkan dan sistem apakah sudah bekerja dengan baik sesuai dengan kebutuhan pengguna atau tidak. pemeliharaan termasuk memperbaiki berbagai kesalahan yang mungkin akan timbul setelah sistem diimplemantasikan.

\subsection{Analisis Kebutuhan}

Analisis kebutuhan dilakukan dengan terjun langsung ke lapangan dengan tujuan untuk mendapatkan data sebanyak mungkin yang berhubungan dengan penjualan kopi di Do'i Coffee. Setelah data terkumpul digambarkan lah proses bisnis dengan menggunakan activity diagram dan dilakukan Analisa masalah terkait kegiatan penjualan produk pada Do'i Coffee dengan menggunakan alat bantu fishbone diagram [7] Adapun kegiatan pengumpulan data dilakukan melalui:

a. Observasi

Observasi ini dilakukan di Toko Do'i Coffee. Dilakukan untuk memantau dan mangamati kegiatan yang terjadi pada toko yang terkait dengan kegiatan penjualan produk yang ada di toko tersebut. 
b. Wawancara

Dilakukan untuk mendapatkan data secara langsung melalui proses tanya jawab langsung dengan pemilik toko adapaun pertanyaan seputar kegiatan penjualan produk di toko tersebut.

c. Analisis Dokumen

Analisis dokumen dilakukan dengan mengumpulkan semua dokumen yang digunakan selama kegiatan proses penjualan produk ditoko, seperti bukti order, struk, daftar menu, laporan-laporan dan lain-lain.

d. Studi Literatur

Dalam penelitian ini penulis melakukan review terhadap beberapa penelitian dari penulis-penulis sebelumnya mengenai penerapan e-commerce berbasis content management system untuk meningkatkan penjualan, diantaranya adalah :

1) Menurut penelitian Nurul Azwanti berjudul Sistem Informasi Penjualan Tas Berbasis Web Dengan Pemodelan UML tentang membuat aplikasi berbasis website yang digunakan sebagai sarana penjualan dari Mendi Shopping dengan hasil akhir berupa pembuatan website untuk pemesanan tas secara online karena lebih mudah dalam hal waktu dan tempat [4].

2) Menurut penelitian Sandi Kosasih dengan judul Perancangan sistem E-Commerce Untuk Memperluas Pasar Produk Oleh-Oleh Khas Pontianak membahas tentang proses penjualan oleh-oleh yang masih kurang efisien dan jumlah pembeli yang masih sangat terbatas dengan hasil akhir yaitu Membuat suatu aplikasi web yang berbasis E-Commerce, yang akan dibangun menggunakan bahasa pemrograman PHP untuk menghasilkan sistem yang dapat memberikan kemudahan [5].

3) Menurut penelitian Eka Rini Yulia, Siti Ernawati dan Risa Wati dengan judul E-Commerce Onderdil Motor Menggunakan Waterfall Model Studi Kasus pada Bengkel Proklamasi Jaya Motor, membahas tentang Membahas penarapan media pemasaran berbasis E-Commerce dengan menggunakan metode waterfall, bertujuan untuk membantu penjualan onderdil motor yang semakin meningkat dan tingkat kepuasan pelanggan meningkat karena tidak perlu lagi datang secara langsung ke bengkel saat akan membeli onderdil motor yang diperlukan, karna bisa di pesan secara daring. [6].

\subsection{Desain Sistem}

Tahap ini digunakan untuk merancang dan mengembangan sistem yang akan diusulkan agar bisa menyelesaikan permasalahan yang sudah teridentifikasi sebelumnya, diawali dengan merancang Business Mode Canvas (BMC) yang sesuai dengan Do'i Coffee agar bisa mengikuti bisnis terkini, dan merancang kebutuhan sistem secara fungsional dengan menggunaan use case diagram, merancang hubungan antar data yang terintegrasi dan model data dengan menggunakan class diagram, Class diagram juga merupakan salah satu diagram yang terlibat dalam pengembangan sistem berorientasi obyek. [10], merancang komunikasi antara actor dan sistem teknologi informasi dengan menggunakan sequence diagram dan membuat rancangan layar untuk setiap fungsionalitas sistem yang sudah dirancang sebelumnya, rancangan layar pada penelitian ini menggunakan bantuan perangkat lunak Balsamiq Mockup. Diagram-diagram ini merupakan hanya sebagian dari diagram yang ada didalam Unified Modelling Language (UML) [9].

\subsection{Implementasi Sistem}

Implementasi sistem adalah tahapan penggunaan sistem oleh pengguna secara langsung sesuai dengan kebutuhan sistem, adapun kegiatan ini terdiri atas:

1. Implementasi Website (Domain)

Domain adalah nama unik diinternet yang dapat digunakan sebagai alamat sebuah website.

2. Implementasi Website (Hosting)

Hosting adalah space memory di internet yang dapat digunakan untuk menyimpan file- file dan media lainnya dari sebuah website

3. Implementasi Website (CPanel)

Cpanel atau dikenal juga dengan kontrol panel adalah sebuah halaman aplikasi website terproteksi yang digunakan untuk mengakases program-program pendukung website dalam web server/web hosting, cpanel menjadi jembatan untuk mempermudah pengelolaan website oleh pengguna. Adapaun cpanel disini menggunakan Content Management System E-Commerce wordpress.

\subsection{Testing Sistem}

Testing ini bertujuan untuk memastikan bahwa website siap untuk digunakan dan tidak terdapat lagi error atau bugs dalam setiap halaman website. Adapun testing sistem menggunakan Black Box Testing dimana cara 
kerjanya adalah melakukan evaluasi dari tampilan layar website dan fungsionalitasnya apakah berfungsi dengan baik atau tidak. Jika ternyata tidak baik maka dilakukan perbaikan lagi pada halaman fungsionalitas tersebut.

\section{HASIL DAN PEMBAHASAN}

\subsection{Activity Diagram Pemesanan Produk}

Berikut merupakan Activity Diagram sistem usulan pada kegiatan penjualan kopi pada Do'i Coffee yang akan dilakukan secara online:

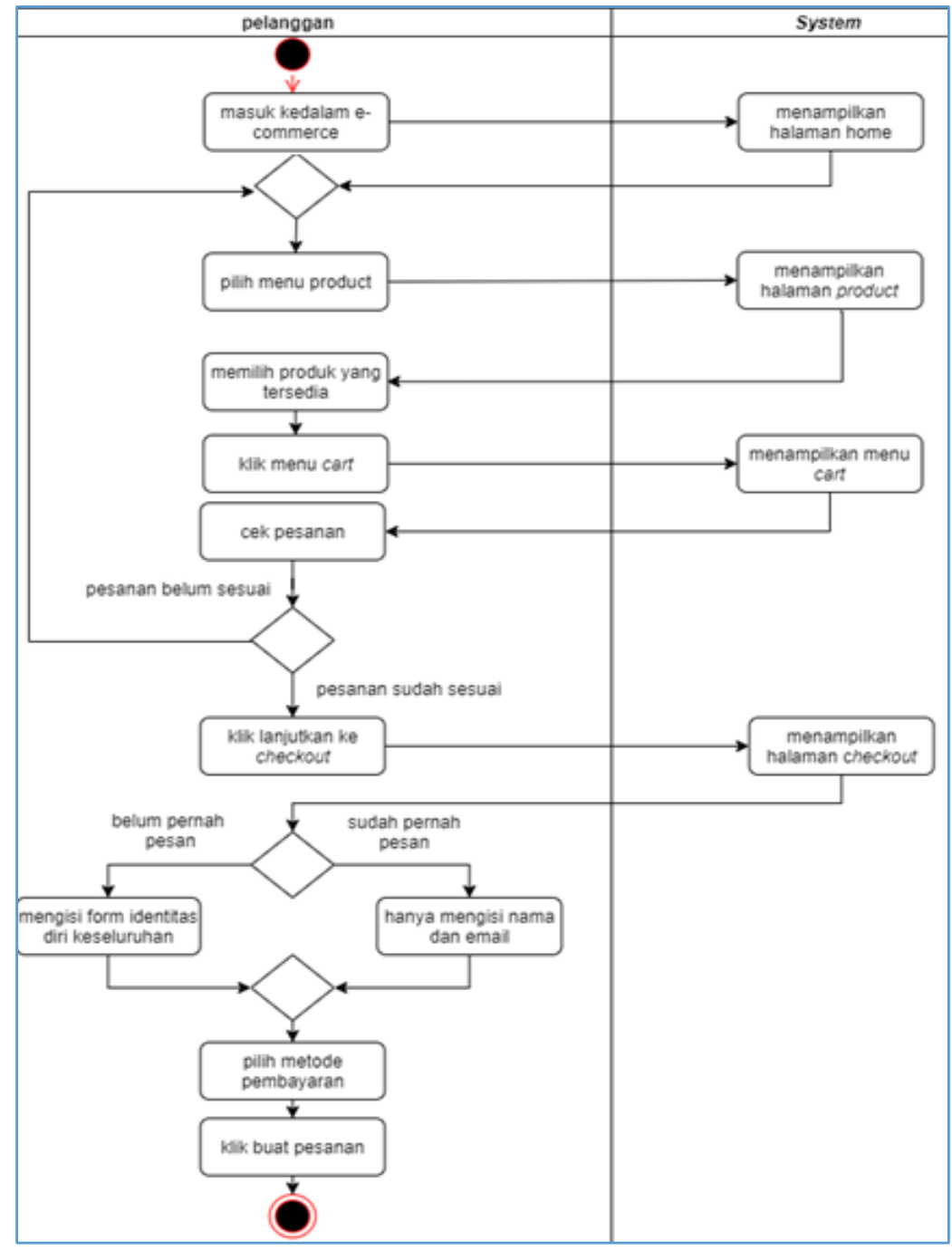

Gambar 1. Activity Diagram Pemesanan Produk

Pada Gambar 2. Activity Diagram Pemesanan Produk memperlihatkan aktivitas-aktivitas yang dilakukan oleh pelanggan pada saat berhubungan dengan sistem, mulai masuk dalam website e-commerce yang dirancang, memilih produk yang diinginkan, apabila tertarik membeli maka pilih menu cart pada halaman web dan jika ingin menambahkan produk berikutnya dengan mengulang proses dari awal tadi, sehingga akhirnya pelanggan diminta untuk mengisi alamat pengiriman sesuai dengan format yang ada di halaman web toko dna memilih jenis pembayaran.

\subsection{Analisis Masalah (Fishbone Diagram)}

Digunakan untuk menganalisa permasalahan lebih lanjut yang terjadi pada do'i coffee yang berhubungan dengan proses penjualan produk, diketahui permasalahan yang sudah teridentifikasi mengakibatkan penguasaan pangsa pasar penjualan kopi kurang luas kalah bersaing dengan toko-toko sejenis. 
available online at http://jom.fti.budiluhur.ac.id/index.php/IDEALIS/index

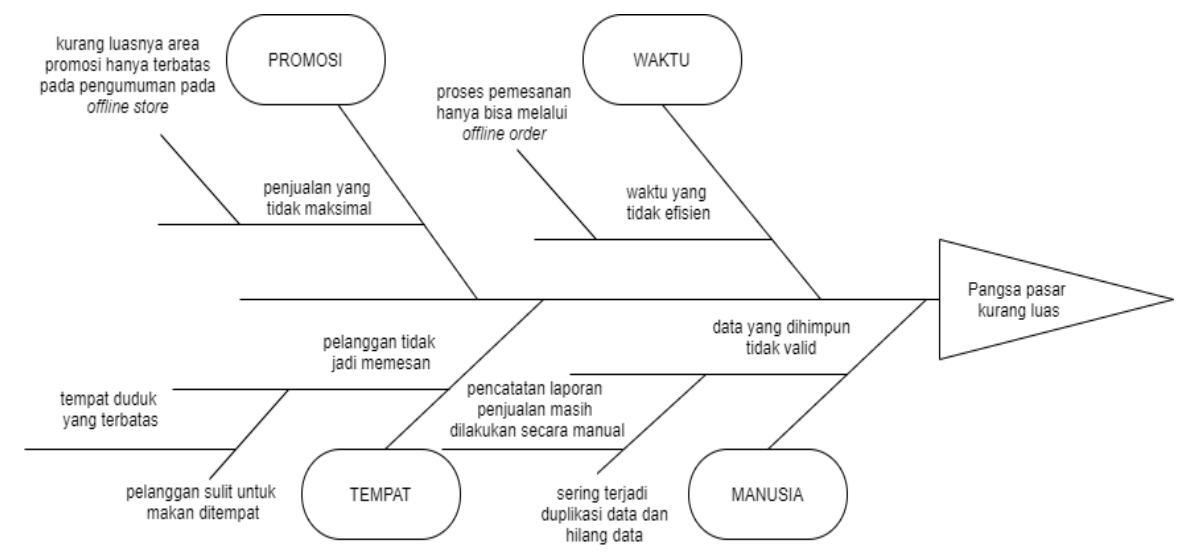

Gambar 2. Analisis Masalah Do'i Coffee

Analisis fishbone tedapat permasalahan utama yaitu pengsa pasar penjualan kopi do'i coffee kurang luas disebabkan oleh proses pemesanan hanya bisa mulalui datang langsung ke toko, pencatatan laporan penjualan masih dilakukan secara manual, kurang luasnya area promosi dan tempat duduk di toko yang terbatas, seperti pada Gambar 3.

\subsection{Use Case Diagram}

Gambar berikut merupakan gambar dari use case diagram [10] dari sudut pandang owner, barista dan pelanggan use case diagram tersebut menggambarkan interaksi barista \& Owner dengan sistem. Dan interaksi antara pelanggan dengan admin sistem.
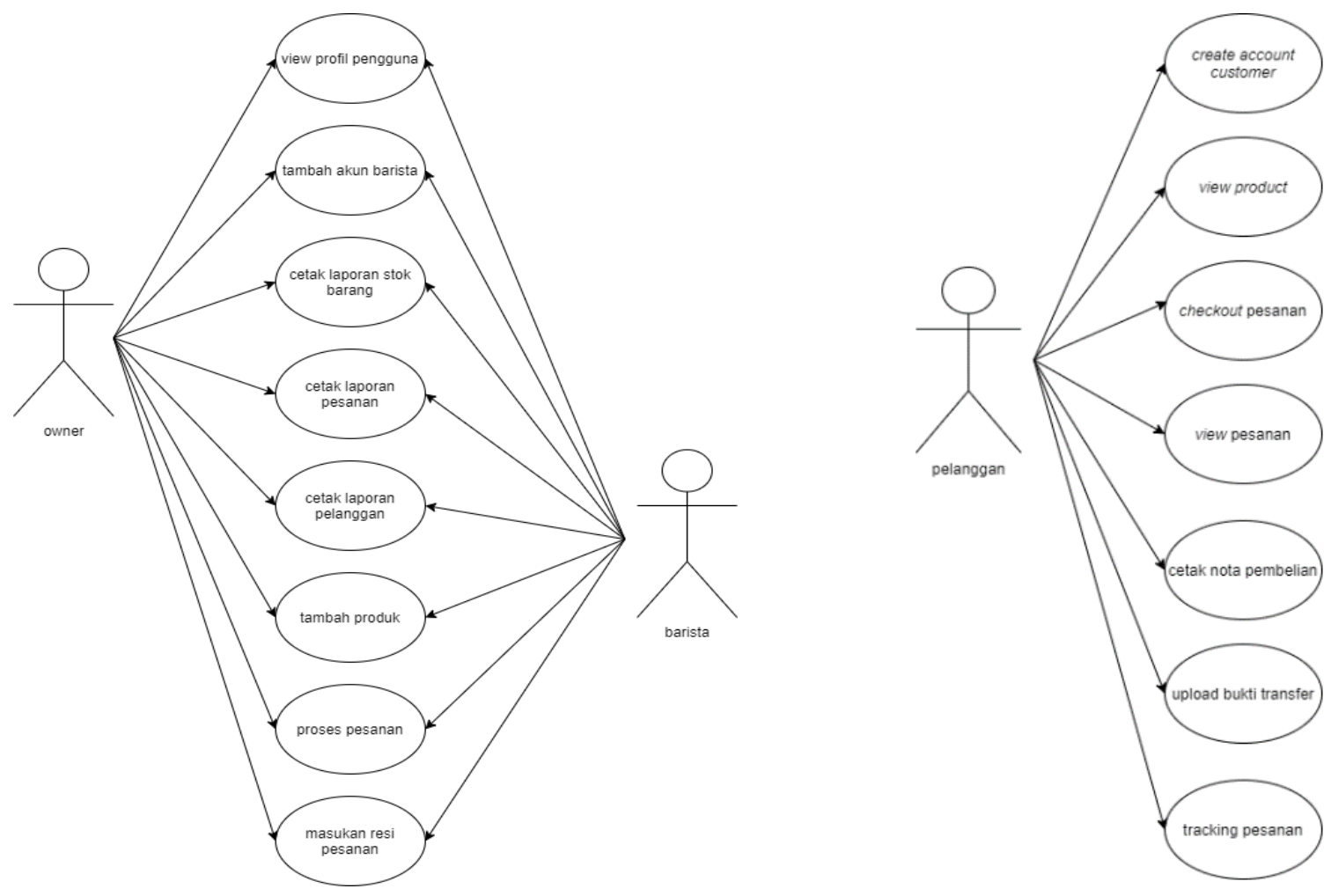

Gambar 4. Use case Diagram Owner, Barista dan Pelanggan

Berdasarkan use case diagram diatas terdiri atas owner dan barista bisa menagkases view profile pengguna, tambah akun barista, cetak laporan-laporan dan tambah produk, proses pesanan dan memasukkan resi pesanan. 
Adapun pelanggan bisa mengakses create account customer, view product, checkout pesanan, view pesanan, cetak nota, upload bukti transfer dan tracking pesanan, seperti pada Gambar 4.

\subsection{Class Diagram}

Seperti yang ditunjukkan pada Gambar. 5 memperlihatkan rancangan basis data yang berupa class diagram [10], rancangan database ini digunakan pada sistem penjualan pada do'i coffee menggunakan e-commerce dan plugin tambahan woocommerce.

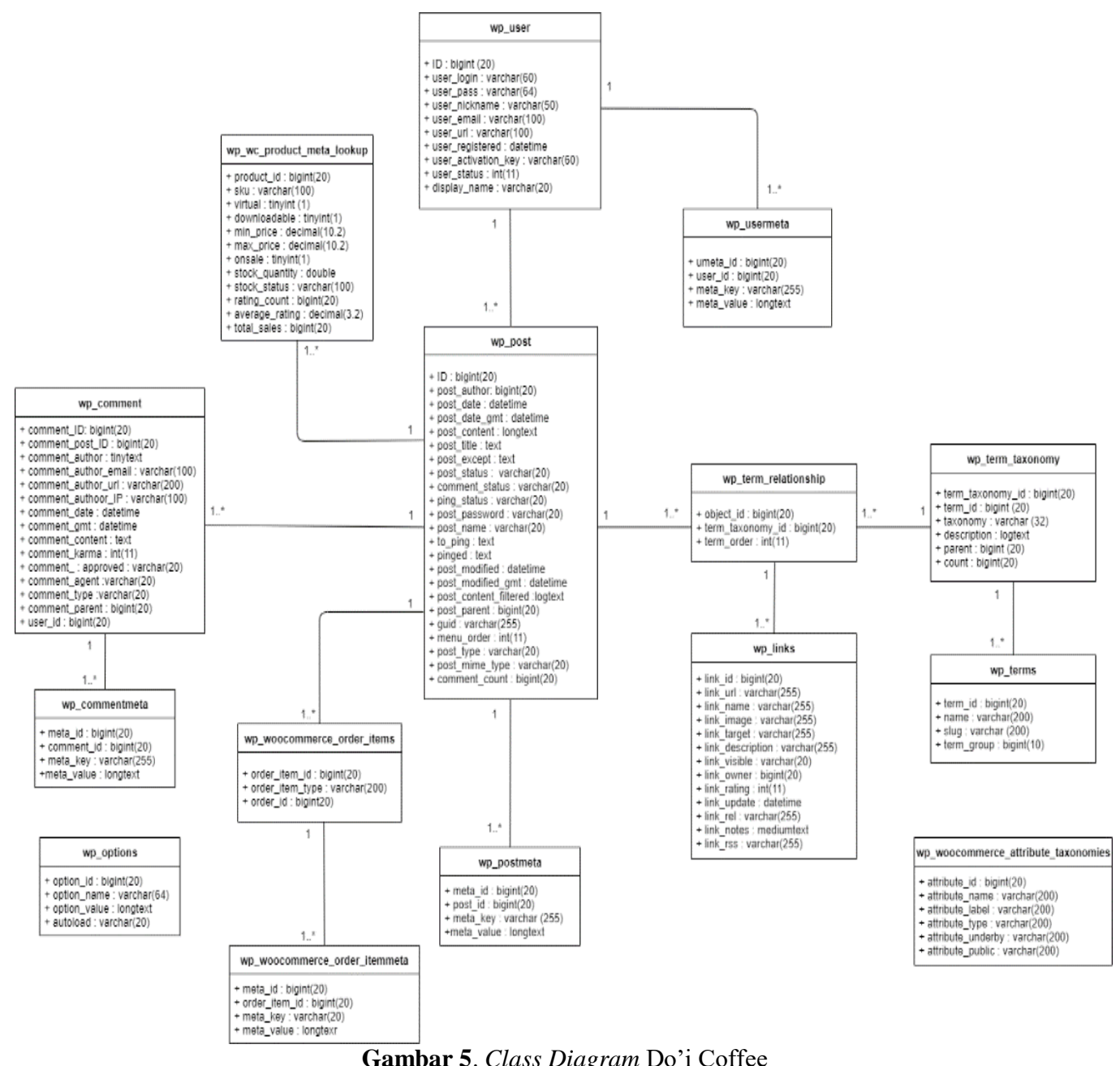

Rancangan class diagram diatas merupakan hasil keluaran dari instalasi software CMS wordpress, dan setelah melakukan pengaturan di cpanel agar sesuai dengan fungsionalitas sistem yang diinginkan dihasilkan lah model class diagram seperti pada Gambar 5.

\subsection{Hasil Keluaran Penelitian}

Adapun hasil keluaran dari penelitian ini untuk membantu menyelesaikan permasalahan yang sudah teridentifikasi sebelumnya, berupa sebuah website yang bisa diakses dari komputer atau smartphone dari para penggunanya yang sudah terhubung ke jaringan internet. Berikut merupakan beberapa halaman website dari penjualan kopi pada do'i coffee 
INDONESIA JOURNAL INFORMATION SYSTEM (IDEALIS)

Volume 4, Nomor 2, Juli 2021

ISSN 2684-7280 (online)

Halaman 242-249

available online at http://jom.fti.budiluhur.ac.id/index.php/IDEALIS/index

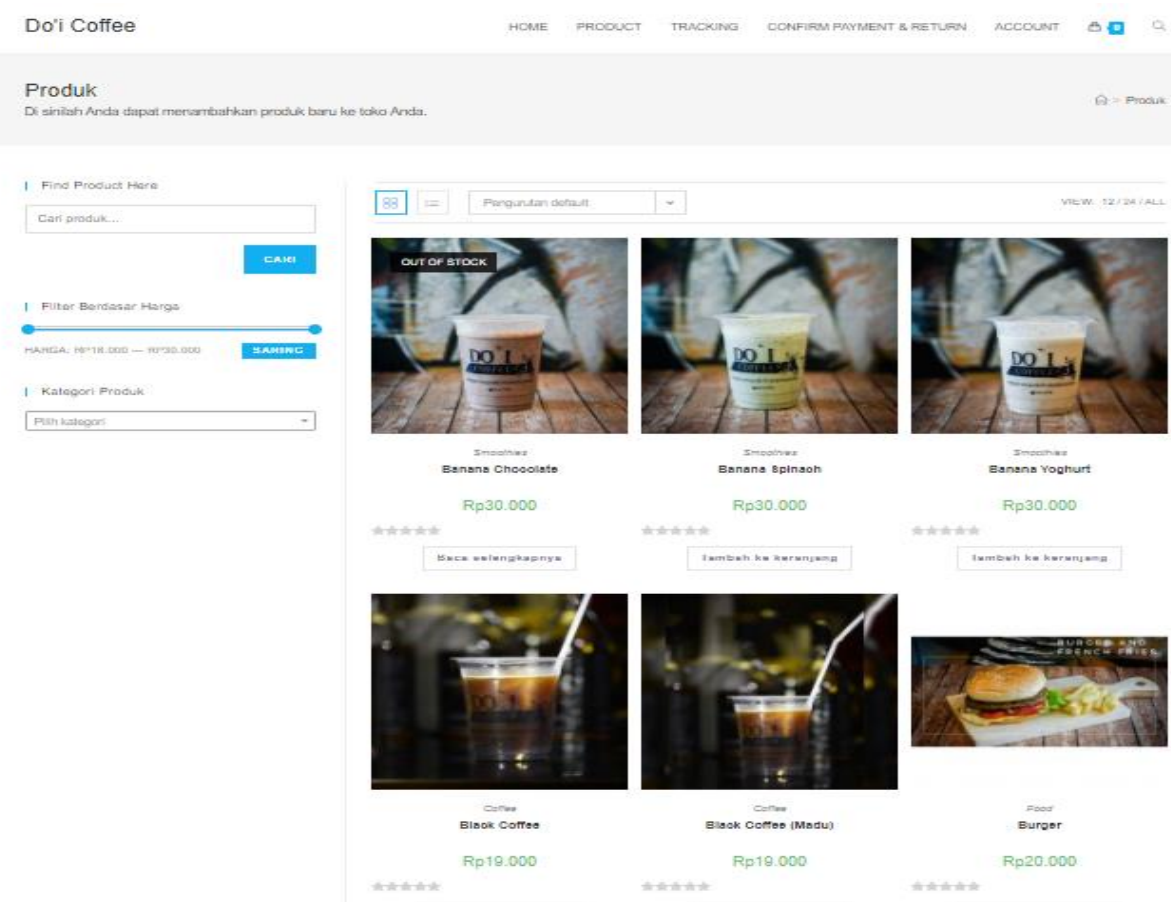

Gambar 6. Tampilan Menu View Product

Pada Gambar 6. Menampilkan halaman yang berisi semua daftar produk yang dijual oleh toko, lengkap dengan gambar dan informasi yang terkait produk tersebut. Jika pengguna memilih salah satu gambar produk maka akan menampilkan halaman berisi informasi produk secara rinci.

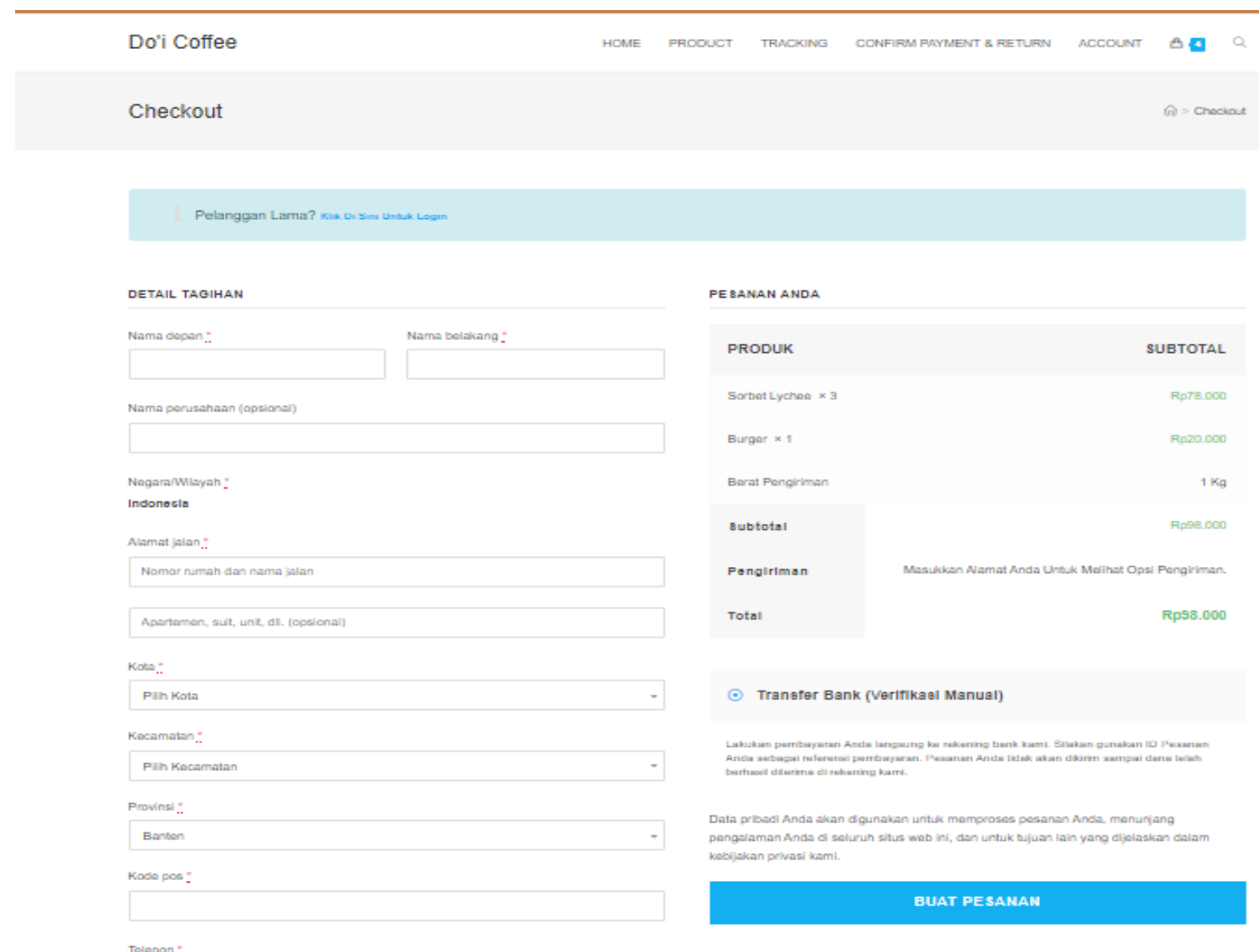

Gambar 7. Tampilan Menu Checkout 
Tampilan menu checkout pada Gambar 7, berisi tentang informasi mengenai metode pembayaran dan alamat pengiriman yang diinginkan oleh pengguna. Disini pengguna akan memilih jenis pembayaran yang diinginkan dan memasukkan alamat kirim dari pengguna tersebut

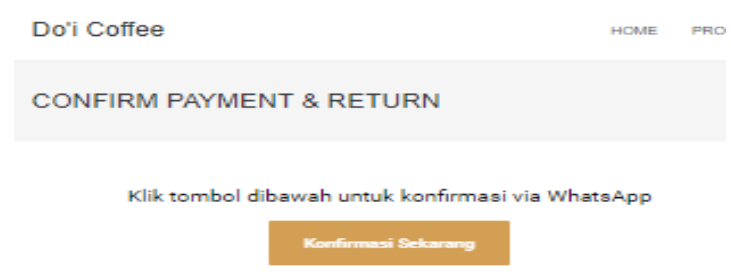

Gambar 8. Tampilan Menu Confirm Payment

Tampilan menu confirm payment ini bertujuan untuk mengkonfirmasi pembayaran yang telah dibayarkan oleh pelanggan kepada penjual agar pesanan dapat dilanjutkan. Seperti pada Gambar 8.

\section{KESIMPULAN}

Setelah mengetahui permasalahan dan hasil pembahasan yang dialkukan pada penelitian ini maka didapatkan kesimpulan bahwa (a) Pelanggan tidak perlu lagi datang ke toko karena bisa memesan secara online dengan mengakses www.kedai doi coffee.my.id. (b) Mengefisiensikan waktu dalam proses pemesanan karena hanya perlu memesan dengan mengakses www.kedaidoicoffee.my.id untuk memudahkan pemesanan dan pembayaran. (c) Dengan adanya fitur katalog produk yang ada pada website, maka pelanggan dapat dengan mudah mengetahui harga, stok dan rincian produk yang dijual oleh Do'i Coffee. (d) Pengolahan data penjualan tersimpan dengan baik dan terorganisir karena menggunakan rancangan basis data sistem penjualan Do'i Coffee secara daring (wordpress version). (6) Dengan adanya fitur cetak laporan stock, complete order, dan cancelled order, maka akan mempermudah pemilik toko untuk membuat laporan stock, complete order, dan cancelled order serta mengurangi terjadinya human error pada saat melakukan pencetakan laporan. (7) Dengan adanya fitur list produk pada website e-commerce, maka akan mempermudah pemilik untuk mengecek setiap produk yang dijual.

\section{DAFTAR PUSTAKA}

[1] M. S. Hotana, "Industri E-commerce Dalam Menciptakan Pasar Yang Kompetitif Berdasarkan Hukum Persaingan Usaha," Jurnal Hukum Bisnis Bonum Commune, vol. 1, no. 1 pp. 28-38, 2018.

[2] Irwan Isa, Reengineering Sistem Informasi, Yogyakarta: Graha Ilmu, 2012.

[3] M. Susilo, "Rancang Bangun Website Toko Online Menggunakan Metode Waterfall," InfoTekJar (Jurnal Nasional Informatika dan Teknologi Jaringan), vol. 2, no. 2, pp. 98-105, 2018.

[4] N. Azwanti, "Sistem Informasi Penjualan Tas Berbasis Web Dengan Pemodelan UML," Kumpulan JurnaL Ilmu Komputer (KLIK), vol. 04, no. 01, Februari 2017, pp. 1-14, 2017.

[5] S. Kosasi, "Perancangan Sistem E-Commerce Untuk Memperluas Pasar Produk Oleh-Oleh Khas Pontianak", SNASTIA 2015, Oktober 2015, pp. 111-119.

[6] E. R., Yulia, S. Ernawati and R. Wati, "E-Commerce Sparepart Motor Menggunakan Metode Waterfall (Studi Kasus: Bengkel Proklamasi Jaya Motor)," Jurnal Teknik Komputer AMIK BSI, vol. 4, no. 2, pp. 7-12, 2018.

[7] M. Coccia., "The Fishbone Diagram To Identify, Systematize And Analyze The Sources Of General Purpose Technologies," Journal of Social and Administrative Sciences, vol.4, no.4, pp. 291-303, 2017.

[8] W. Irmayani and E. Susyatih, "Sistem Informasi Anggaran Pendapatan dan Belanja Desa Berorientasi Objek," Khatulistiwa Informatika, vol. 5, no. 1, pp.58-63, 2017.

[9] P. S. Aji and D. Mahdiana, "Penerapan Metode SAW Pada Sistem Penunjang Keputusan Penilaian Calon Asisten Lab ICT Terpadu Universitas Budi Luhur," Jurnal IDEALIS, vol. 2, no .4, pp.154-158, 2018.

[10] R. A. Sukamto and Shalahudin, M., Rekayasa Perangkat LunakTerstruktur Dan Berorientasi Objek, Bandung: Informatika Bandung, 2014. 